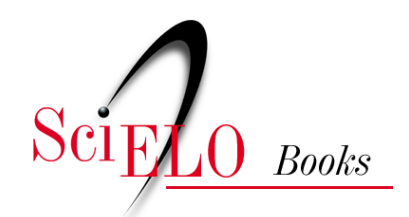

Editora da UESC

\title{
Originalidade e precariedade do método fenomenológico husserliano
}

\author{
Sanqueilo de Lima Santos
}

\section{SciELO Books / SciELO Livros / SciELO Libros}

SANTOS, SL. Originalidade e precariedade do método fenomenológico husserliano. In: LIMA, ABM., org. Ensaios sobre fenomenologia: Husserl, Heidegger e Merleau-Ponty [online]. Ilhéus, BA: Editus, 2014, pp. 15-50. ISBN 978-85-7455-444-0. Available from SciELO Books $<$ http://books.scielo.org $>$.

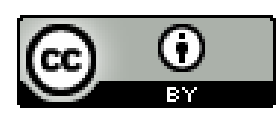

All the contents of this work, except where otherwise noted, is licensed under a Creative Commons Attribution $\underline{4.0 \text { International license. }}$

Todo o conteúdo deste trabalho, exceto quando houver ressalva, é publicado sob a licença Creative Commons Atribição 4.0.

Todo el contenido de esta obra, excepto donde se indique lo contrario, está bajo licencia de la licencia Creative Commons Reconocimento 4.0. 


\section{Originalidade e precariedade do método fenomenológico husserliano}

\section{Sanqueilo de Lima Santos}

Nas reflexôes a seguir serão considerados os problemas que servem de ponto de partida para a inauguração do método fenomenológico e, sem descurar da atitude crítica, avaliar, ao mesmo tempo, em que medida as propostas de Edmund Husserl se mantêm num nível programático. Para isso, servirão de objeto de análise Investigaçôes Lógicas, Ideias I e Meditaçôes Cartesianas.

Através do seu método fenomenológico, Husserl pretende fixar, para os problemas filosóficos herdados do idealismo alemão e, por extensão, da filosofia moderna do sujeito, o modo verdadeiramente radical e fundamental de investigar filosoficamente e de alcançar um conhecimento teórico filosófico isento de confusão e mal-entendidos. O tema do método é recorrente em todo o legado do filósofo. E uma vez que em cada escrito husserliano a apresentação do mesmo vem acompanhada da preocupação de afastar os mal-entendidos e as imprecisóes, a originalidade e o caráter promissor do procedimento fenomenológico se confirma em implicaçóes metódicas, a cada vez, novas, e em caracterizaçôes cada vez mais precisas. Mais adiante, algumas palavras serão dedicadas a esse ponto. 
As fontes de mal-entendidos e imprecisóes se encontram naquilo mesmo que é posto em questão nas críticas husserlianas. Esse pano de fundo da crise da filosofia e da crise epistemológica náo pode ser negligenciado. Ele contém as motivaçôes do esforço husserliano com vistas a reafirmar a importância da investigação filosófica via um método próprio para os problemas que realmente lhe dizem respeito.

Quanto à legitimação da filosofia, o trabalho de Husserl é inegavelmente um marco na história da filosofia contemporânea. Mesmo que a corrente do positivismo lógico e da filosofia analítica se autodenominem portadora da última palavra em temas atuais da filosofia, a virada linguístico-pragmática está longe de representar o único movimento filosoficamente importante nos séculos XIX e XX; sem mencionar que o tema da significação vinculada ao signo linguístico recebeu um tratamento fenomenológico-husserliano em vários momentos ${ }^{1}$. É também digno de nota que, em nenhum momento, Husserl tenha negligenciado o objetivo e a especificidade da fenomenologia, nem a ideia essencial do que elegeu como autêntico campo de pesquisa filosófica: a subjetividade pura. Muitos filósofos se inspiraram em sua obra, apropriando-se de seus conceitos ou expressóes, mesmo sem ter declarado explicitamente tal apropriação ${ }^{2}$.

1 Semelhante preocupação com a relação entre o signo ou o símbolo e a significação, Bedeutung, ou o sentido, Sinn, aparece na Filosofia da Aritmética (1891), nas Investigaçóes Lógicas (1911), na Lógica Formal e Transcendental (1929). (N. do. A).

2 A título de exemplo. A expressão Dasein, substantivada e consagrada por Heidegger, já aparece na forma verbal em Ideias II (1912), como da sein, para se referir ao modo de dação do homem no mundo circundante, an- 
Todavia, as caracterizaçóes sempre novas alcançadas por Husserl, bastante precisas, diga-se de passagem, carecem, todavia, de desenvolvimento. Quando são desenvolvidas, i.e., quando são aplicadas a temas específicos, levam a novas postulaçôes nos campos da reflexão e da pesquisa, mediante as quais Husserl retoma as grandes afirmaçôes programáticas. Nisso se constata uma precariedade, às vezes desconcertante, porque ao lado da originalidade do método fenomenológico, perfeitamente justificado por suas motivaçôes históricas, a expectativa de um desenvolvimento mais positivo termina, frequentemente, suspensa.

\section{A pureza das essências nas Investigaçóes Lógicas}

Considera-se que a fenomenologia, como projeto husserliano que assume um papel explicitamente filosófico, tem seu momento inicial nas Investigaçóes Lógicas. Antes de sua primeira edição, em 1901, Husserl havia começado o seu percurso intelectual no campo da matemática, investigando-a como um tema epistemológico particular. Alguns elementos, contudo, que seriam retomados mais tarde, já estavam presentes de forma embrionária, e.g., a tese de que unidades objetivas

\footnotetext{
tes de qualquer construção teórica ou filosófica a seu respeito. Basta lembrar, também, a ocorrência, na mesma obra, de Körper e de Leib, para se referir distintamente ao corpo, no primeiro caso, ao corpo físico, como é tematizado objetivamente, e, no segundo caso, ao fenômeno originário do corpo como órgão subjetivo das sensaçôes e dos movimentos livres fundados no querer; distinçáo táo cara a Merleau-Ponty. Grande parte das premissas do Imaginário de Sartre também se encontra em Fantasia e Consciência da Imagem (1904-1905) de Husserl. (N. do A.).
} 
ideais se constituem a partir de operaçóes subjetivas, a especificação de uma evidência intelectiva, a noção de signo vazio e a polêmica com o psicologismo. Nas Investigaçóes Lógicas, a questão espistemológico-filosófica acerca da matemática dá lugar ao problema da lógica enquanto teoria universal da ciência; a finalidade se aprofunda e o escopo se amplia.

A obra se divide em seis Investigaçóes, mas começa, na verdade, com um extenso trabalho crítico, nos Prolegômenos. Nesse último, todo o esforço é envidado no sentido de invalidar as teses psicologistas que pretendem, de forma exaustiva, explicar o fato do conhecimento, não só o obtido no campo empírico, mas incluindo o que é construído na lógica e na matemática, com base somente nas causas naturais subjacentes aos processos cognoscitivos.

Para Husserl, qualquer reflexão a respeito dos aspectos essenciais do conhecimento teórico (o sujeito, o objeto, a lógica, a relação entre conceitos, a proposiçáo etc.) que tenha aderido, tácita e ingenuamente, ao suposto de que ele é um fato; que o entenda dessa maneira e tire conclusóes com base nesse entendimento naturalizante, está, por princípio, emaranhada em equívoco, sendo vítima de uma confusão inevitável e insuperável enquanto mantiver esse pressuposto. $\mathrm{O}$ que motiva ainda mais a interpretação naturalística é a inegável existência fática do conhecimento. O problema é reduzi-lo ao lado fático e tomar esse último como resposta para questóes essenciais. Em vez de uma reflexão feita em bases naturalísticas, a problematização filosófica válida do conceito de ciência, de teoria científica e de lógica das ciências que pretenda atingir com êxito seus aspectos essenciais, encontra seu fundamento em princípios isentos de contingências, em evidências apodícticas e em leis essenciais. 
Nesse sentido, as essências, corretamente compreendidas na sua função estritamente formal e ideal, distinguidas categoricamente de qualquer factualidade, não podem ser senão puras (reinen Wesen). Só quando fato e essência estáo distinguidos um do outro de modo mutuamente exclusivo é que a correlaçáo entre ambos se torna inteligível: todo fato instancia uma essência, nenhum fato pode ser dado prescindindo-se de sua essência. A essência é uma forma de caráter ideal, e só se mostra ao ser instanciada num fato.

Mas o que é essa pureza? E mesmo que seu conceito permaneça meramente negativo (o não contingente, o não dubitável, o não real-causal), onde detectar tal pureza? $\mathrm{Na}$ ausência de pressuposiçóes tácitas inadvertidas, que pressuposto deve aparecer temática e explicitamente? À fenomenologia e ao seu método compete a tarefa de responder a essas e a qualquer questão dessa espécie. Husserl acredita que o método da análise intencional, que define a fenomenologia nessa fase da primeira década do século XX, é capaz de dar acesso às leis puras essenciais do conhecimento. Esse não é mais abordado em seu lado fático, mas passa a ser investigado, em seus aspectos formal e ideal, como um fenômeno puro da consciência. Nesse primeiro momento, o método descritivo da psicologia de Brentano serve de modelo, fazendo com que a fenomenologia husserliana se caracterize basicamente como descrição de vivências da consciência. Fazendo do procedimento descritivo o modelo a ser adaptado, a execução da fenomenologia principiante pode ser resumida como segue:

1. O princípio da intencionalidade, tomado de empréstimo da psicologia descritiva de Brentano, diz que toda consciência é consciência de algo, distinto dela mesma; 
2. O conhecimento é produzido por um sujeito intencional como uma efetuação consciente sua, através de suas vivências;

3. As vivências valem para o sujeito e ele as possui como fenômeno, e como tal não são reais, consistindo, em vez disso, de um conteúdo puramente ideal. O conhecimento é um momento não independente dessas vivências;

4. A fenomenologia alcança o fenômeno do conhecimento enquanto conteúdo ideal. Ela o faz ao tematizar as puras essências inerentes à intencionalidade do sujeito.

Em correlação com esses elementos, o alcance da conceituação da própria fenomenologia, que é feita no $\mathbb{S} 5$, do Apêndice da Sexta Investigação, faz-se suficientemente compreensível. O contexto visa precisar o conceito de "aparição", que pode ser habitualmente tomada como, (i) a vivência concreta da intuição; (ii) o objeto intuído, enquanto tal, hic et nunc ou (iii) os componentes da vivência, e.g., as sensaçôes. De acordo com Husserl, o segundo é o conceito originário de aparição, i.e., "do que aparece, ou ainda, do que pode aparecer, do intuitivo enquanto tal" (HUSSERL, 1996, p. 206), e é o que interessa para a fenomenologia. A "apariçáo", no sentido do que aparece, enquanto tal ${ }^{3}$, é o tema objetivo para o qual o ato intencional se dirige enquanto aparece à consciência, é o que se

3 Esse "o que aparece, enquanto tal” receberá, em obras maduras de Husserl, uma designação própria, será o noema, na acepçáo fenomenológica, ou ainda, o algo de que se tem consciência enquanto tal, na correlaçáo noético-noemática, funcionando continuamente na vida da consciência. (N. do A.). 
chama propriamente "fenômeno", no registro husserliano. De acordo com semelhante conceito de fenômeno, Husserl delimita a fenomenologia como uma ciência, apresentada na forma que segue. Primeiro, delimitando seu campo temático objetivo:

Tendo em vista que todas as espécies de vivências (incluindo-se entre elas as vivências do intuir externo, cujos objetos são por sua vez chamados de apariçóes externas) podem também vir a ser objetos de intuiçóes reflexivas e internas, chamaremos 'fenômeno' tudo aquilo que é vivência, na unidade de vivência de um eu: a fenomenologia é, por conseguinte, a doutrina [Lehre, que é preferível entender como 'ciência' ou 'teoria'] das vivências em geral, abrangendo também a doutrina [ciência] de todos os dados, não só os genuínos, mas também os intencionais, que podem ser evidenciados nas vivências (HUSSERL, 1996, p. 207).

Em continuidade ao que foi dito, ele exclui o modo de abordagem naturalístico e insiste na "pureza" dos temas que interessam à fenomenologia, frente a quaisquer elementos factuais. Nesse sentido, o filósofo define:

A fenomenologia pura é, portanto, a doutrina [ciência] das essências dos 'fenômenos puros' dos fenômenos da 'consciência pura' de um eu puro - isto é, ela não se situa no terreno dado pela apercepção transcendental [apreensão transcendente] da natureza física ou animal, ou seja, psicofísica, ela não faz nenhuma espécie de experiência posicionante ou de juízo posicionante que se relacione com objetos transcendentes à consciência; ela não estabelece, em consequência, nenhuma espécie de verdades sobre realidades físicas ou psíquicas (e, portanto, nenhuma 
Sanqueilo de Lima Santos

espécie de verdade psicológica, no sentido histórico) e não toma nenhuma dessas verdades como premissa ou tese (HUSSERL, 1996, p. 206, grifos do autor).

Na mesma continuidade chega-se, então, a uma especificação do método fenomenológico. Tudo o que era factual, ôntico ou mundano não se perde, mas sofre uma modificação, muda de valor e significado segundo o modo como passa a ser tematizado na reflexão, começa a valer como fenômeno para a consciência e a esse título é conservado. E explica:

Em vez disso, todas as apercepçóes e juízos posicionantes que visam além dos dados da intuição adequada e puramente imanente (isto é, que visam além do puro fluxo de vivências) são tratados pela fenomenologia puramente como as vivências que são em si próprias, e submetidos a uma investigação puramente imanente e puramente 'descritiva'. Ao mesmo tempo, sua investigação das essências é pura, ainda num segundo sentido, o da 'ideação'; no sentido próprio ela é uma investigação apriorística (HUSSERL, 1996, p. 207).

Nas Investigaçóes Lógicas, o projeto da fenomenologia se firma no gesto de dar início a uma ciência apriorística das vivências imanentes à consciência. Tudo o que foi acrescido e aprofundado depois, incluindo o reconhecimento do solo de problemas comuns à tradição moderna e idealista alemã, não foge ao espírito dessa formulação ainda tateante, mas que porta um valor verdadeiramente pioneiro. No entanto, e por causa mesmo do pioneirismo, algumas limitaçóes são perceptíveis. De um autor que propóe uma ciência inaugural, esperase que ele a realize, mesmo que no nível rudimentar. Husserl 
é, sem dúvida, um autor sistemático; e não só isso. Não lhe faltam o atento olhar crítico em relação às ideias centrais da tradição moderna e idealista, e aquelas difundidas em seu tempo, bem como o trabalho duro de submeter ao seu método de investigação esses mesmos problemas. Mas sua obra, desde o começo até os últimos escritos de sua vida, trazem o tom de "introdução" de "iniciação", de "convite" ou de justificação e explicitação da "tarefa a ser feita". Talvez, semelhante state of affair se dê por uma intrínseca necessidade da fenomenologia que, em virtude de sua própria índole, a aprisiona em seus próprios recursos heurísticos, como aquele que se debate na areia movediça.

Para se fazer notar essa precariedade, ela já aparece nas Investigaçóes Lógicas no tema das leis, no projeto de uma gramática lógica pura e de uma teoria das multiplicidades puras. Tais intentos não são absurdos, nem contraditórios, e, além disso, estão bem justificados. É possível entender o lugar que elas ocupam na problemática levantada. Só que não chegam a ser desenvolvidas. As "leis", se é possível depreendê-las do texto das Investigaçôes, devem ser reconhecidas nas "necessidades de essência", seja a respeito da vivência, seja a respeito do seu correlato. Em todo caso, são leis no sentido de racionalidade. "Versam" sobre o rasgo de racionalidade reconhecível nas vivências intencionais. Assim, podem, entre outros, ter o sentido de leis formais.

Os já conhecidos princípios da lógica clássica - o da identidade, o da náo-contradiçãao e o do terceiro excluído -, são exemplos de necessidade essencial. Outros dizem respeito às categorias de objeto e às teorias ontológicas. À fenomenologia cabe vincular, de forma inteligivel, essas necessidades, já conhecidas ou por conhecer, com as necessidades essenciais 
intrínsecas às vivências. Em vários momentos, Husserl usa expressôes como "por necessidade essencial...", "é parte da essência de...", "a lei essencial...", aplicando-as às várias espécies de vivências. Mas entre enunciados desse tipo e um desenvolvimento explícito, há uma grande distância. Enunciados desse tipo, se não forem explicados claramente à luz da intencionalidade $^{4}$, e no registro da pureza autoimposta, podem ocorrer em contextos não fenomenológicos (no metafísico, no da reflexão espontânea etc.).

Com o plano de sistematizar as leis que estruturam as categorias objetivas e as vivências intencionais, com base no modo segundo o qual as unidades de significaçâo se conectam entre si, Husserl postula as mencionadas teorias, a das leis lógico-gramaticais puras e das leis das multiplicidades puras. As primeiras seriam para regular o limite e a diferença entre sentido (Sinn), sem sentido (Unsinn) e contrasentido (Widersinn). As segundas, para regular a composição de unidades objetivas nominais em conjuntos subordinados e superordenados. $\mathrm{O}$ problema e o nome da solução ficam assim dados. Mas ao

4 Um esforço de Husserl nesse sentido pode ser detectado em Experiência e Juizo (1930) e na Lógica Formal e Transcendental (1929). Na primeira, a descrição de vivências pré-objetivantes, antepredicativas e pré-categoriais precede a formação do juízo, está na sua gênese. As formas puras (as leis) que regulam tais juízos são as categorias fixadas por Kant. Na segunda, mais precisamente, nos suplementos, são abordadas algumas formas sintáticas, alguns conectivos e classes gramaticais da linguagem natural, sob o ponto de vista intencional. Mas, além da forma "juízo" e, além da "experiência básica do objeto da percepção sensível”, Husserl não avança e se abstêm do problema com a metáfora do "entrelaçamento", das "camadas de sentido", da textura ou do nexo "inextrincável" como imagens que habitam a "corrente das vivências". (N. do A.). 
estudioso que apostar na proposta husserliana, fica a missão de desenvolver, ele mesmo, por sua conta e risco, as mencionadas "leis" (Gesetzen) e suas consequências.

\section{A eidética descritiva em Ideias I}

Ideias I (1913) traz uma explícita adesão ao idealismo e ao projeto da filosofia transcendental alemá. Isso se reflete na colocação de novas bases, novas metas e conceitos. $\mathrm{O}$ método também não se define mais apenas enquanto "reflexão" sobre a forma a apriori das vivências intencionais e seus vividos. $\mathrm{O}$ projeto husserliano continua a se autodenominar "fenomenologia” (o que, aliás, será mantido). O que muda é a forma de delimitar o que "aparece" para a consciência, o que é fenômeno seu. Em tudo o que compóe a esfera da consciência reside o significado transcendental. Nas Investigaçóes, tratava-se de entender o sujeito cognoscitivo na forma pura, a priori de sua intencionalidade, com a universalidade e idealidade que acompanham as formas puras. Em Ideias I, o problema é enunciado como o de uma filosofia transcendental, e o ego puro, autor e depositário dos fenômenos, quaisquer que sejam, é também ego transcendental, no sentido de que a constituição do sentido da totalidade dos objetos, os atos de doação de sentido de um e o mesmo de cada objeto e de doação de validez transcendente (objetivo-real) se fazem na trama de intencionalidade desse ego.

É possível ver o reflexo dessas modificaçóes da fenomenologia nos seguintes aspectos:

1. Na conceituação da consciência. A correlação entre $\mathrm{o}$ ato da consciência (com seu raio intencional) e o 
correlato objetivo puramente intencional desse ato passa a se chamar correlação noético-noemático. As suas unidades sintéticas, nexos noético-noemáticos. Os nexos recorrentes como habituais no sujeito explicam a formação de estratos de sentido persistentes. Dependendo de qual seja o estrato que ocupe o primeiro plano da consciência, em dado momento, fazendo com que os outros recuem para o pano de fundo do ego, surgirão diversas atitudes, que são modos consciência particulares. Tudo isso passa a caracterizar a consciência.

2. No método, que era de reflexão e ideação, e passa, agora, a comportar momentos e ramificaçōes. Deve, assim, conter o momento da epoché fenomenológica, que é a fundamental, e outras reduçôes para dar conta de fenômenos específicos, e.g., a redução eidética (que tematiza as categorias ou as formas dos entes), a epoché abstrativa (que tematiza a distinção entre o "meu" e ou "estranho"). Não pode mais se limitar, com isso, a tratar genericamente (indistintamente) todos os correlatos de atos, como correlatos objetivos, que exemplificam unidades ideais de significação, "sem mais". Precisa vincular o estrato de sentido de cada atitude à sua "região ontológica" correlata. E ver, além do mais, as formaçóes objetivas de sentido dentro de um desenvolvimento intersubjetivo.

3. No alcance, que após uma consideração acentuadamente lógico-epistemológica na fase precedente, adquire uma veia transcendental que ocupará o centro de interesse. $\mathrm{Na}$ realidade, o que explica toda a reformulação da consciência, diferenciada internamente, e 
as várias funçôes e sistemas, o novo modo de compreender o próprio método de abordagem intencional, com momentos e etapas distintos, com uma forma própria de explicitar seus temas, é a pretensão de dar ao projeto filosófico da fenomenologia um alcance transcendental.

Para que a fenomenologia possa reivindicar o qualificativo de filosofia e estar à altura de responder aos problemas impostos pelo cientificismo e seu relativismo, ela deve ser capaz de se pronunciar acerca da verdade e da realidade como um todo (o mundo), em sentido universal, assim como a respeito das condiçóes de possibilidade do conhecimento e do saber teóricos, em uma palavra, ela precisa se firmar como fenomenologia transcendental. O seu método, calcado no sistema da consciência, precisa ser apto a responder, a partir daí, os problemas colocados nesse nível. Tendo começado com o problema da forma lógica do conhecimento, já renunciando a pressupostos factuais e às teses extraídas das ciências de fato, este era o caminho inevitável da fenomenologia. Pelo menos, depois de Kant, nenhuma desculpa pode ser dada a um pensamento filosófico centrado na subjetividade que queira evitar a problemática transcendental.

Ao se reconhecer como transcendental, o campo de investigação da fenomenologia, o ego puro, adquire o sentido mais fundamental de subjetividade transcendental, é reconhecido (ou precisa sê-lo) como gerador e garantidor da realidade transcendente, que Kant colocava sob a problemática rubrica do "em-si". O ego puro, assim, torna pensável e acessível aquilo que não está, nem pode estar realmente incluído em sua pureza a priori, senão a título de mera possibilidade. 
O processo gerado pela atuação do ego, atuação doadora de possibilidade e sentido, que permite alcançar os entes transcendentes e, conjuntamente, o mundo transcendente, é denominado constituição. Em virtude da constituição, o perceber, o pensar, o representar, o intuir etc., se exercem espontaneamente como intencionalidades validadas em suas funçôes específicas. Um desenvolvimento sistemático da fenomenologia constitutiva é encontrado em Ideias II (19121929). O trabalho de constituição é contínuo, começa com as vivências antepredicativas, pré-categoriais, prossegue em todas as etapas do conhecimento que existe em cada região objetiva, do natural ao teórico, e culmina na autoconstituição da intersubjetividade transcendental. Nesse percurso o mundo é o terminus a quo e o terminus ad quem. A doaçáo de sentido e validez que acompanha cada intenção começa em um mundo previamente dado e culmina na reconquista desse mesmo mundo no nível transcendental, ou seja, em seu verdadeiro ser, filosoficamente justificado.

Deve-se observar, porém, que essa progressão constitutiva náo é algo simples, como se a doaçáo de sentido e validez fosse um ato invariável, funcionando para todas as espécies de realidade. Quando se coloca em questão o estatuto de realidade dos objetos, ou o estatuto de independência ideal dos mesmos, com a autonomia vigente em seu modo de ser, se adentra numa problemática propriamente ontológica. A constituição, que inicialmente contempla apenas o modo como emerge a unidade de sentido do que é visado intencionalmente, deve assumir, a partir de certo nível, um sentido ontológico; deve remeter às sínteses puramente subjetivas também a consciência da realidade e da verdade intrínseca à consciência de algo objetivo. 
Cumpre levar em conta que, na fenomenologia, a ontologia náo é um corpo de conceitos homogêneos pensados por uma consciência igualmente genérica e homogênea. A constituição é uma gênese que comporta ramificaçôes. A ontologia é regional e a consciência é internamente diferenciada em atitudes. A unidade do ser é uma projeção feita sobre uma base complexa e heterogênea; a unidade da consciência se reduz à de um sistema funcional e multiestratificado. A constituiçáo lida com uma multiplicidade de entes que se organizam de acordo com as regióes materiais. E cada regiáo comporta uma forma que a insere na regiāo pura formal. No processo constitutivo, os nexos noético-noemáticos, ao se delimitarem como atitudes distintas, estão, ou visam estar, sincronizados com as regiōes dos entes. E essas regiōes, ao se estabilizarem como estratos de sentido, asseguram a normalidade da atitude e da experiência. A fenomenologia deve explicitar ambos os aspectos na eidética descritiva, na descrição das formas noético-noemáticas e na descrição dos conceitos objetivos assim gerados. A possibilidade da experiência depende desse intrincado de fatores subjetivos e objetivos.

Para o leitor de Ideias I, contudo, fica uma perplexidade muito semelhante à que foi sentida em face da gramática lógica pura e da teoria das multiplicidades puras. Onde estáo desenvolvidas semelhantes ontologias? Em Ideias II, obra inegavelmente sistemática, riquíssima em análises e distinçôes, são trabalhadas três regiôes: natureza material (a coisa física), natureza animal (alma ou psiquismo) e mundo espiritual. Uma preocupação é assegurar a especificidade do mundo espiritual e, com isso, a autonomia das ciências do espírito. Uma série de fenômenos é abordada. Mas não fica fixada, como resultado, cada regiáo, enquanto um corpo teórico nitidamente delineado, com suas respectivas categorias regionais. 
Trata-se de um simples adiamento, em favor de reflexóes mais urgentes que teriam permanecido em promessa? $\mathrm{Ou}$ se trata de uma limitação intrínseca ao método? A epoché, definida como suspensão dos juízos de existência, como renúncia a todo pressuposto realista, e, correlativamente, autoimposição de um idealismo radical, se veria perplexa diante do fluxo concreto das vivências e, portanto, incapaz de delimitar qualquer forma permanente de conceitos teóricos mais concretos? Essas são algumas questôes que imediatamente e, mais uma vez, se impóem, ficando a cargo do estudioso buscar as respostas por conta própria e risco.

\section{A intersubjetividade transcendental nas Meditaçóes Cartesianas}

Em 1929, nas Meditaçóes Cartesianas, Husserl intenta justificar expressamente o interesse filosófico que o liga à filosofia primeira de Descartes, interpretando o ego cogito no nível transcendental. A ideia de filosofia primeira remonta a Aristóteles e tem forte acento teológico. $\mathrm{O}$ aspecto teológico da prima philosophia não é, porém, reassumido por Husserl. Seu reconhecimento dirige-se para o alcance transcendental que está potencialmente dado na descoberta do ego cogito. Esse eu pensante é o eu ao qual se atribui a propriedade de ter consciência de algo em geral, de ter, como momento essencial dessa consciência, autoconsciência, de ter consciência do mundo (da realidade como um todo), sendo, em todo caso, o eu intencional. Mesmo que Descartes tenha chegado a ele mediante a dúvida hiperbólica, o que o ego contém de valioso não seria uma reserva inalienável de verdades absolutas, ocultando 
a chave para reinvestir de certeza toda a realidade que foi posta em dúvida, emprestando, ao restante das coisas, a evidência de sua apercepção intuitiva.

Não se nega o valor da operação da dúvida. É ela que impede de incluir o ego entre entes transcendentes, i.e., entre os fatos. No momento da dúvida, o ego se mostra isento de todo elemento real existencial. $\mathrm{O}$ ego cogito, enquanto intui a si mesmo como puro pensamento em ato, dá mostras do tipo de evidência que acompanha, tacitamente, todo ato de consciência: a evidência imanente, inalienável à consciência, contínua e essencialmente aderente à corrente de vivências, ou melhor, inerente a elas. $\mathrm{O}$ momento da evidência inseparável do ego cogito, o sujeito reflexivo em sua apodicticidade imanente, é que tem, para Husserl, o valor e a exemplaridade da vida transcendental: é reconhecido como protótipo do ego transcendental. A intencionalidade, variável e múltipla, na multiplicidade dos atos, é, contudo, o que permanece imanente, é o elemento que contém a chave de investigação própria da filosofia primeira. Está presente no ego cogito na medida em que para todo cogito, há um cogitatum correlato.

Em virtude desse entendimento do ego cogito em seu significado transcendental, a epoché fenomenológica deve ser empregada em lugar da dúvida metódica, porque a dúvida, ao suprimir tudo o que existe realmente, por ampliação indevida, suprime também (invalida) todos os atos subjetivos voltados para os objetos. A epoché, não obstante, faz do sistema de todos os atos subjetivos imediatamente acessível à autoconsciência do ego reduzido, o tema de investigação, colocando entre parênteses a referência que esse sistema comporta naturalmente com respeito aos entes transcendentes.

Reafirmam-se, nas Meditaçôes, os princípios que haviam sido erguidos em Ideias I. Há, também, uma ressonância da 
preocupação mais ampla atinente à posição e à tarefa que competem à filosofia, relativamente às ciências objetivas, sendo recolocado o contraste entre a ciência transcendental e as ciências particulares 5 . O método da epoché e o recurso à evidência imanente apodítica surgem na esteira dessa problemática. Dando a entender que se está diante da necessidade de um "giro copernicano", imagem, aliás, empregada por Kant na Crítica da Razão Pura, Husserl diz:

Em primeiro lugar, quem quiser tornar-se filósofo deverá 'uma vez na vida' voltar-se para si mesmo e, dentro de si, procurar inverter todas as ciências admitidas até aqui e tentar reconstruí-las (HUSSERL, 2001, p. 1).

A palavra "inverter" significa compreender a objetividade a partir da subjetividade, para o que não cabe empregar senão a epoché fenomenológica. As críticas voltadas para o particularismo, o objetivismo ingênuo, a fragmentação do saber e sua desvirtuação meramente técnica, e para o relativismo na sua versão mais preocupante voltam a ser postas, e o diagnóstico é sempre o mesmo: todos esses problemas que colocam a filosofia em descrédito e retiram das ciências sua

5 O retorno a esse tema está, aliás, no núcleo dos esforços e preocupaçóes husserlianos. O sentido estrito de ciência transcendental e ciências positivas particulares será um dos motivos-chave da Crise. A "decaída das ciências" em "artes teóricas", pontuada no $\mathbb{S} 56$, nada mais seria que a consequência de sua perda do autêntico sentido de ciência, fundado na universalidade e radicalidade do pensamento transcendental, perda decorrente do abandono das questóes últimas da razão, pressuposta por essas mesmas ciências.(N. do A.). 
inteligibilidade última decorrem da falta de uma fundamentação transcendental da ciência e de um método filosófico apto à sua realização. Para o filósofo, o método por ele proposto teria esse papel.

Nas Meditaçôes Cartesianas, Husserl parte da distinção entre ciências fáticas, apenas como "fenômeno cultural", e "ciências no sentido verdadeiro e estrito". Para a ciência no segundo sentido, "a evidência perfeita e seu correlato, a verdade pura e estrita apresentam-se como uma ideia inerente à tendência de conhecer" (HUSSERL, 2001, p. 5). Ora, empírica ou faticamente, não é possível alcançar algo como uma "ideia inerente a...". Apenas no uso da razão pura poder-se-ia chegar a um pressuposto apriorístico deste tipo. A razão, mesmo a pura, é um pressuposto das ciências. Assim, Husserl acrescenta: "[...] a ciência quer verdades válidas de uma vez por todas e para todos, definitivas, partindo de verificaçóes novas e finais" (HUSSERL, 2001, p. 5). Por princípio, ela o quer, porque, de fato, está sempre a caminho de chegar ao cumprimento dessa pretensão. A filosofia transcendental não vem para suprir semelhante falibilidade das ciências, nem para aperfeiçoar o seu método de ajuste aos fatos. Contendo uma "imperfeição teorética essencial”, elas, no entanto, pressupóem um mundo, fazem a seu respeito a imagem de um todo ordenado internamente, com níveis de regularidade mais ou menos acessíveis. Assim como uma racionalidade subjacente aos juízos, o sentido de um mundo verdadeiro é o pressuposto de suas pretensóes de validade. No fundo, sua crítica, dirigida tanto contra a filosofia quanto as ciências, visa recolocar o tema cartesiano do mundo enquanto tema caro à filosofia transcendental, ressaltando a importância crítica e construtiva (acesso à evidência) da epoché fenomenológica. 
Pode-se assim dizer que a epoché é o método universal e radical pelo qual me percebo como eu puro, com a vida de consciência pura que me é própria, vida na qual e pela qual todo o mundo objetivo existe para mim, exatamente da forma como existe para mim (HUSSERL, 2001, p. 8, grifo do autor).

A ideia de mundo só é definitivamente concebida e compreendida em seu sentido mais próprio, em seu cerne, quando tomada no modo de consideração transcendental. Uma figura de linguagem bastante conhecida é construída com a expressão "desde que o mundo é mundo..."; à qual se seguem de costume verdades de fato. $\mathrm{Na}$ perspectiva transcendental o mundo só é mundo quando é mediado pela vida da consciência pura, e é nela estabelecido, antes de tudo, a título de aparição; só nessa mediação e aparição pode referirse a um ego. Só chega, porém, a ser assim tomado, quando se constata que não é nas ciências fáticas, parciais, nem mesmo numa cosmologia geral objetivista, que se encontra a fonte de justificação última dessa ideia.

A ideia de mundo só é genuína se for aquela que contém o sentido válido de mundo. Ela reside na subjetividade transcendental, cuja vida transcorre totalmente no ego puro. Como diz Husserl, "não posso viver, experimentar, pensar; não posso agir e emitir julgamentos de valor num mundo outro que aquele que encontra em mim e tira de mim mesmo seu sentido e sua validade" (HUSSERL, 2001, p. 5). O mundo pode existir sem mim, mas, nessa hipótese, toda sua ordem ou desordem concreta, "para si”, e tudo aquilo de que é feito "em si" s, são insuficientes para

${ }^{6}$ As expressóes estão entre aspas justamente porque não são de uso 
explicar que eu posso ter a seu respeito múltiplas formas de consciência. O ego é a fonte de justificação última da ideia de um mundo objetivo, tão necessário às ciências. Sem a trama interna de relaçôes intencionais, sem as sínteses noéticas parciais, sem as atitudes e as regiôes ônticas correlatas, que convergem para a ideia de uma unidade do cosmo, não se poderia legitimar nem considerar racionais as proposiçóes científicas.

A epoché parte de uma análise baseada na primeira pessoa do singular. A captura e a tematização inaugural da subjetividade transcendental dão-se quando me reconheço, no modo da reflexão, enquanto eu transcendental. Toda reflexão voltada, intuitiva e imediatamente, para os atos da consciência é autoexame; toda reflexão que visa à esfera originária da consciência é autorreflexão. Só que tudo o que se obtém no nível da primeira pessoa, a rigor, até que se prove o contrário, tem validade apenas para aquele que realiza a descoberta. Se outro sujeito tiver outro resultado, outro será também o critério de validade, e este poderá reivindicar igual direito ao assentimento. Dessa forma, se não for possível passar do soli ipse do ego ao outro e ao nós intersubjetivo, o mesmo relativismo que Husserl acusa veementemente nas ciências particulares será imputável à sua fenomenologia transcendental, que pretende ser ciência universal. Assim, toda contribuição que o método pode trazer, acima descrita, só não será ilusória se conseguir evitar uma recaída no solipsismo.

Não se passa por esse problema pelo alto. A constituição do mundo espiritual objetivo, de um espírito não apenas do

fenomenológico, indo, aliás, de encontro à sua proposta. As aspas têm uma função crítica. (N. do A.). 
indivíduo que é um eu, mas de comunidades intersubjetivas que aparecem no nós, ocupa significativamente as obras de maturidade de Husserl. Nas Meditaçóes Cartesianas, esse "nós intersubjetivo", ao mesmo tempo em que se recobre com a objetividade, aprofunda seu pressuposto intencional, subjetivo, porquanto comporta as características de uma "personalidade de nível elevado". Assim como ao eu individual corresponde uma "pessoa”, um conjunto objetivo de disposiçóes e hábitos, uma história, uma expressividade e uma personalidade enquanto conjunto de fins éticos conscientemente assumidos, há, para as comunidades formadas por uma pluralidade de indivíduos, uma unidade solidária de fins, um conjunto regulado de costumes, instituiçóes, uma história coletiva, semelhante a uma personalidade suprapessoal, de "nível superior", pois seus fins se sobrepóem aos fins meramente individuais.

Para compreender e conceder legitimidade à intersubjetividade histórica, cumpre fundamentar primeiramente a sua possibilidade e assegurar a sua fonte de sentido na intersubjetividade transcendental. Se a experiência transcendental começa em primeira pessoa, urge descortinar a intersubjetividade a partir do ego transcendental. A intersubjetividade transcendental, se ela elimina o solipsismo e o relativismo, como se espera, deve garantir a universalidade presumida em toda objetividade. Como a universalidade procede da intersubjetividade transcendental, torna-se uma questão inevitável.

A ruptura do solipsismo, se ela visa alcançar todos os sujeitos racionais, necessita, pelo menos de início, atingir um segundo sujeito, o outro. A doação do outro, sem desvio de sentido em mero corpo físico ou simples vida animal, mas sim, com o pleno e justo sentido de outro eu, de outro contraposto a mim, enquanto eu mesmo (lembre-se a referência recíproca de 
mesmo/outro) faz-se através de uma forma única e peculiar de intencionalidade. Somente a "empatia" (Einfühlung) visa intencionalmente, no outro, uma autoconsciência com a mesma profundidade egológica e subjetiva pressuposta no uso autorreferente da palavra "eu". A mesma autoconsciência, inerente ao uso de "eu" como o sujeito na oração, é posta no outro. A conquista do solo objetivo comum da intersubjetividade deve começar, segundo Husserl, pela constituição do outro.

O problema é portanto antes de tudo bem peculiar, pondo-se justamente como o Ai-para-mim [Für-mi$c h-d a]$ do outro, enquanto tema, por conseguinte, de uma teoria transcendental da experiência do estranho [Fremderfahrung], a assim chamada empatia (HUSSERL, 1950, p. 123-124, grifo do autor).

Semelhante problema não aflige a atitude ingênua. A empatia, tranquilamente, faz parte da experiência diária. A comunicação e a compreensão mútua, que pressupóem a consciência do alter ego, integram a espontaneidade do sujeito. $\mathrm{Na}$ atitude natural não se vê dificuldade quanto a isso, pois o medium da linguagem faz da expressão que circula entre nós um factum. A vigência da intersubjetividade também é pressuposta sem problemas na atitude natural e espontânea, e.g., sob as noçôes correntes de "público", de "bom-senso", de "realidade comum a todos", de "mundo compartido" ou de "interação social". Tal estado de coisas faz com que a fenomenologia necessite de um método para descobrir e surpreender, na empatia, o momento propriamente intencional, aprofundando o seu significado como intencionalidade.

Uma epoché mais profunda, e mais radical deve ser efetuada no interior da própria subjetividade transcendental. Sobre 
o ego, já reduzido com relação ao mundo, efetua-se a epoché abstrativa, na qual se coloca entre parênteses toda formação de sentido que não tem sua fonte primitiva no eu próprio. $\mathrm{O}$ que é próprio se distingue do que é estranho, no interior da vida imanente.

$A$ redução de meu ser à minha esfera transcendental própria ou ao meu eu mesmo transcendental e concreto, por meio de uma abstração exercida em relaçáo àquilo que a constituição transcendental me apresenta como estranho a mim mesmo, possui um sentido muito especial. [...] $\mathrm{Na}$ atitude transcendental e na abstração constitutiva de que acabamos de falar, meu ego, o ego do sujeito que medita, não se confunde no seu ser transcendental próprio com o eu humano habitual; náo se confunde com o $e$, reduzido a simples fenômeno, no interior do fenômeno total do mundo (HUSSERL, 2001, p. 108, grifos do autor).

Essa epoché apresenta ao próprio sujeito o seu eu humano natural como "simples fenômeno", porque a epoché abstrativa se mantém no nível transcendental da epoché fenomenológica. A redução fenomenológica já tem esse resultado de proceder reflexivamente apenas sobre o ego puro e a partir dele, deixando o eu empírico real entre parênteses. $\mathrm{O}$ dado novo é que, ao eliminar as formaçôes de sentido oriundas de constituições que não são minhas, e conservar apenas as minhas próprias constituições, mesmo esses fenômenos nascidos de minha própria subjetividade já confrontam o ego com um rasgo de estrangeirismo; em virtude da própria índole da consciência de dirigir-se a algo distinto dela mesma, opondo a si mesma um polo de fenômenos. Tal é a primeira "figura" com que o outro se dá. 
Mas somos tocados aqui por um fato notável, eis um encadeamento de evidências que, em seu próprio encadeamento, têm aparência de paradoxos: ao eliminarmos o que nos é 'estranho', não alcançamos o conjunto da minha vida psíquica, à vida desse eu psicofísico; minha vida permanece experiência do 'mundo' e, portanto, experiência possível e real $d a-$ quilo que nos é estranho (HUSSERL, 2001, p. 112, grifos do autor).

Reconhecida a função de dirigir-se ao estranho como um traço inerente à intencionalidade, e, assim, como um momento essencial do próprio ego transcendental, implicado na esfera imanente, o próximo passo é entender como o estranho recebe o qualificativo de outro eu. Nem todo estranho é sinônimo de outro eu. Para que isso ocorra, são necessárias algumas condiçôes: (i) a condição transcendental do alter ego; (ii) a analogia com os movimentos livres do corpo; (iii) a intencionalidade empática. Estas são condiçôes que trabalham em conjunto, numa rede de interdependência.

Primeira condiçãa, o ego que se reflete na experiência do estranho como um ego transcendental, em tudo comparável ao meu, mas numericamente distinto, é um alter ego. Esse alter ego é análogo ao ego transcendental próprio, e sua presença concomitante está implicada necessariamente em toda experiência de mundo, na condição de outro sujeito coconstitutivo desse mundo. Pressupôe-se que o "mundo só é mundo", de pleno direito e no pleno sentido da palavra, se sua constituição incluir outro ego distinto do ego próprio, a fortiori, porque esta exigência condiciona a possibilidade do próprio ego transcendental atingir o mundo. O ego próprio já é, de saída, ligado transcendentalmente ao alter ego. A situação na qual é 
Sanqueilo de Lima Santos

notória a função transcendental do alter ego é descrita como empareamento, que ocorre por ocasiáo da percepçáo do corpo do outro.

Encontramos [os emparelhados], por uma análise mais precisa, comparecendo essencialmente junto num contágio intencional, introduzindo-se já geneticamente (e na verdade, essencialmente), assim que os emparelhados, ao mesmo tempo, se elevam e se tornam consciente e mutuamente autodespertos [Sich-wecken] em uma reciprocidade, passando do auto-encobrimento para um sentido objetivo (HUSSERL, 1950, p. 142).

Todo o sistema de emparelhamento, assim como qualquer tipo de experiência, evolui em um misto de passividade e atividade; as conexóes que colaboram na unidade de sentido do outro são devidas, em parte, as analogias e associaçóes e, em parte, ao ato de identificação. A constituição do outro, neste sentido, não é como uma aquisição teórica, porque não se passa totalmente sob o crivo da atenção ativa. Na consciência do outro entram muitas conexóes que não foram dadas conscientemente, mas por automatismo, ou mera recepção.

A analogia transcendental e o emparelhamento abrem, porém, o caminho para a segunda condição, que é a analogia do corpo próprio ${ }^{7}$ (Leib) meu com o corpo expressivo e próprio do outro. A analogia também envolve nexos subconscientes e

7 Corpo próprio, ou Leib, é o fenômeno de corpo, órgão da liberdade, centro de orientação e órgão de sensaçôes, "a serviço" da consciência e da intencionalidade. Opóe-se a Körper, como mero objeto físico, sujeito à causalidade real. (N. do A.). 
parte do fato de que se percebem movimentos em corpos que são semelhantes ao meu corpo, movimentos que contêm um sentido, mas que não são explicáveis pela mera causalidade mecânica. Tais movimentos são expressivos e motivados. Para que sejam, porém, movimentos motivados, eles devem proceder de um sujeito intencional, covisado eco-apreendido por mim ao perceber o corpo. Sobre o fenômeno sensível da percepção do corpo alheio funda-se a apreensão do seu sujeito consciente. $\mathrm{O}$ outro eu é, dessa forma, apresentado em concomitância com as aparições do seu corpo. Na apresentação, a essência alter ego, apriorística, é exemplificada em um caso concreto. Da mesma forma que para as meras coisas, presume-se também para o fenômeno do outro um horizonte de experiência.

Devemos então conseguir uma visão, na intencionalidade implícita e explícita, na qual o outro ego se exprime e se comprova a partir do solo de nosso ego transcendental, como, em quais intencionalidades, em quais sínteses, em quais motivaçóes de sentido outro ego se configura para mim e como sendo sob o título de experiência concordante do estranho [einstimmiger Fremderfahrung] e em seu próprio modo, ainda que não se comprove a si mesmo (HUSSERL, 1950, p. 122).

Considerando que a experiência concordante na qual se conhece progressivamente o outro só pode efetuar-se através de vivências da consciência intencionalmente dirigida para o outro eu, e dado que esse outro só pode se destacar tema bem definido na visada da empatia, percebe-se como essa terceira condição está intimamente relacionada com a primeira e a segunda. A empatia visa às apariçôes do corpo alheio como motivadas, e o outro eu basicamente como sujeito de motivaçôes. 
Suas motivaçóes são acessíveis como unidade ideal de significação; mesmo que a esfera primitiva imanente do outro seja, por princípio, inacessível à minha intuição, elas motivam movimentos expressivos, nos quais é possível apreender o sentido das vivências do outro. Minha subjetividade não precisa fundir-se com a subjetividade do outro que expressa cólera, nem preciso reproduzir em mim mesmo a cólera para ser capaz de compreender a respectiva expressão.

Acompanhando o que foi exposto, admitindo o sentido do estranho como intrínseco ao fenômeno do mundo na imanência do ego transcendental, a implicação do alter ego no sentido do estranho, reconhecendo a concretização da essência alter ego na apresentação corporal analógica do outro sujeito, e destacando o papel da intencionalidade empática na experiência acerca de outrem, o passo decisivo para a intersubjetividade é reconduzir o eu e o outro ao solo comum do mundo circundante. Eu e outrem tecemos (no nós transcendental), com nossas consciências, o fio de sustentação do mundo.

[...] no quadro de minha vida de consciência pura transcendentalmente reduzida, experiencio o mundo juntamente com os outros e isso no sentido da experiência de acordo, não por assim dizer com as minhas criações sintéticas privadas, mas sim como estranho para mim, como intersubjetivo, existente para todo mundo, em seus objetos, acessível a todos no mundo (HUSSERL, 1950, p. 123, grifo do autor).

Para fazer uso de uma imagem, pode-se comparar a intersubjetividade transcendental como uma rede de fios amarrados entre si, e que forma uma esfera; cada segmento de fio seria uma intencionalidade empática recíproca; cada nó, na 
rede, um ego transcendental, e o fenômeno do mundo estaria nos vãos abertos entre os fios, e no espaço interno da esfera. $\mathrm{A}$ imagem é só aproximativa, e seus principais defeitos estão em sugerir algo estático, quando a constituição é gerada historicamente, e sugerir algo finito, quando o fenômeno do mundo é, na verdade, inesgotável, assim como a vida transcendental.

Seria oportuno, agora, fazer um balanço. A empatia caracteriza uma consciência originária do outro, não por acesso direto às correntes de vivências do outro, mas do outro como sujeito motivado. Ao apreender as motivaçóes de outrem, a empatia coapreende a unidade de consciência do respectivo alter ego. A empatia não se vê obliterada ou viciada, pelas apariçôes sensíveis, a ponto de confundir o outro com a mera coisa física. A autoconsciência, a consciência do outro e a consciência do mundo convergem em uma única gênese constitutiva transcendental.

Há, na irrupção do estranho dentro da própria vida constitutiva, uma abertura para a experiência do outro mediante uma consciência originária (Originalbewusstsein) do outro, no sentido de que ele é considerado como em "carne e osso" (leibhaftig). Pode-se acrescentar, ainda, muito esquematicamente, com base nas Meditaçóes, que tal gênese constitutiva encerra as seguintes caracterizaçóes:

1. Nada do que é próprio do outro, nada de sua essência própria (Eigenwesen) imanente se torna um dado original (urprünglicherGegebenheit) (HUSSERL, 1950).

2. A experiência do outro se funda na "mediaticidade da intencionalidade"; um representar "aí com" (Mit da): as motivaçóes são coapreendidas "aí com" os movimentos livres expressivos; o alter ego é co-apreendido 
"aí com" o corpo vivo a título de fonte unitária de que procedem as motivaçóes.

3. A experiência do outro, mesmo não dando originariamente a esfera própria do outro, não se dá de forma solta, porque possui o mundo primordial como ponto de partida (primordinalen Welt).

4. O outro aparece como "obra-de-co-presentificação" (Mit-gegenwärtig-machens) e na forma de uma apresentação (Appräsentation) (HUSSERL, 1950).

5. A mediaticidade da empatia, e a co-presentificação resultam do limite básico imposto à consciência do outro: a "apresentação [Appräsentation] que permitisse ao eu próprio irromper dentro da esfera original [Originalsphäre] do outro eu deve ser excluída a apriori" (HUSSERL, 1950, p. 139).

6. Isso leva à doação do outro por "apreensão analogizante" (analogisierendeAuffassung), fundada e motivada na "semelhança" do corpo (Körpe) do outro com o meu, que aparece em minha esfera primordial (Primordinalsphäre) (HUSSERL, 1950).

7. A característica designada por Husserl como pareamento (Paarung) se define pelo fato de que a apreensão do outro por analogia pressupóe uma forma de "síntese passiva", por "associação", como vivências pré-objetivantes - e não apenas a vivência ativa objetivante de identificação. Ela se processa, antes, por "contágio" intencional.

Essa teoria mostra que é possível superar fenomenologicamente o solipsismo. A pretensão de solucionar o problema do solipsismo, contudo, deve ser avaliada. Não há absurdo, 
embora seja paradoxal (como o próprio Husserl assinala), constatar que todo fenômeno próprio abriga uma remissão a outras consciências, que todo fenômeno já contém essencialmente uma vocação para a universalidade. A camada de sentido homogênea própria nunca é definitiva e é sempre questionável graças à heterogeneidade de sentido sempre latente na versão que outrem possui desse mesmo mundo para o qual todos os sujeitos estão intencionalmente dirigidos. A crise de sentido é um traço essencial do próprio sistema de sentidos, como garantia, a priori, da intersubjetividade, e está inscrita na própria esfera imanente. Um ego puro que esteve privado dessa crise abrigaria um sistema de sentidos sempre homogêneo e inalterável; deixaria de ser uma vida. $\mathrm{Ou}$, numa outra hipótese, um ego puro que tivesse a crise, mas privado da essência apriorística "alter ego", sucumbiria a esta crise, em uma confusão ou instabilidade tal que minaria a força unificadora do sistema de sentido, e deixaria, igualmente, de ser uma vida transcendental. A intersubjetividade é condição sine qua non da subjetividade.

Entretanto, nos passos de constituição do outro, acima analisados, uma precariedade pode ser notada. Primeiro, uma intersubjetividade transcendental que constitui "mediatamente", por "analogia” e por "contágio intencional”, não garante que o relativismo solipsista tenha sido supresso totalmente. Mediações e analogias não são intuições, são realizadas por atos significativos, essencialmente indiretos. A experiência que poderia preencher intuitivamente a apreensão de significado das expressóes de outrem, por não ter intuição das vivências que transcorrem no outro, é sempre a de análogos de minhas vivências projetados no outro; nunca as vivências mesmas do outro. Essa experiência é uma contínua interpretação, e as- 
sim, sujeita ao mesmo grau de falibilidade de toda interpretação. As propriedades reais e causais de uma coisa podem ser universalizadas em princípio univocamente, podem coincidir facilmente no conhecimento que todos tenham delas. Mas, a respeito da expressividade de uma mesma pessoa, as motivaçôes e as vivências mais desencontradas, ou mesmo contrárias, podem, de direito, ser opinadas, a depender de quem opina. $\grave{A}$ mesma expressão de alguém, cada um, no exercício da empatia, dará um significado, que pode ser aproximado, mas nunca perfeitamente idênticos, por cada um só comprova por analogia com sua vida imanente. A significação apreendida no outro estará condicionada, tacitamente, pelo repertório de sentido, pelas dúvidas, certezas e hipóteses de cada sujeito. Dessa situação não se espera, na prática, consenso permanente, ou mesmo um consenso. A intersubjetividade transcendental é uma necessidade, mas a constituição trabalha sempre com materiais fragmentários e muito incertos. As comunidades de pessoas fáticas aproximam-se muito remotamente da ideia de uma "personalidade de nível superior".

Uma segunda limitação, muito semelhante às já enunciadas, é quanto à elaboração de uma eidética fundada nos ganhos da epoché abstrativa; de um conjunto inteligível de essências ou de tipos essenciais referentes à empatia, à intersubjetividade, tipos essenciais de expressão interligados a formas definidas de motivação, tudo isso é tarefa a ser realizada. Husserl chega a fazer menção, em Ideias II, de uma gramática ${ }^{8}$

8 Hua IV, 166. Na referida passagem, Husserl também diz que as expressóes da linguagem, e a linguagem verbal, fazem parte também das expressóes corporais. (N. do A.). 
dos movimentos livres do corpo e das expressôes dos conteúdos anímicos, no contexto do problema da empatia. Tal gramática corporal encerraria uma espécie de eidética dos significados implicados na empatia. A ideia está justificada transcendentalmente, mas até que se tente e se consiga concretizá-la em um corpo teórico, fica-se com a dúvida de que seja até mesmo viável.

\section{Consideraçóes finais}

O projeto de uma filosofia transcendental entendida como fenomenologia é uma constante, na obra de Husserl. Para o filósofo, o único modo de a filosofia não se descaracterizar como tal, nem perder de vista a sua autêntica tarefa, é realizando-se como fenomenologia, é atendo-se à experiência transcendental, a qual procede investigando propriamente a esfera imanente, de uma consciência pura ou de uma multiplicidade intersubjetiva de egos. A elaboração de uma filosofia idealista é perfeitamente compatível com o método fenomenológico. Mas, dentro de seu campo, o grau de importância maior vai migrando, ao longo da vida do filósofo, do tema das vivências e dos atos, para o tema do sentido, da doação de sentido e do núcleo de sentido noemático. Esse deslocamento é um progresso mas assemelha-se a sair do mapa e entrar na selva. A correlação noético-noemática encerra, secretamente, o drama do sujeito consciente racional, cuja razão é o princípio atemporal de exigência de unidade, e o mundo concreto (tanto o universo natural, quanto o mundo cultural, histórico), que mostra a todo instante o quanto o uso da razão para o conhecer é limitado e falível. 
O método fenomenológico, ao se embrenhar nos problemas da origem do sentido, da sua gênese na história individual ou ao tentar fazer uma genealogia das ciências historicamente dadas, remontando às motivaçôes primordiais de seu momento inaugural, deveria se deparar, certamente, com a necessidade de muitas eidéticas novas, como ramos da fenomenologia. Não se tratar, nesse ensaio crítico, de denunciar o suposto fracasso do projeto transcendental, como se fosse um fato que trouxesse a invalidação definitiva da fenomenologia, nem de imputar a Husserl todo o trabalho por fazer, que depois, como testemunha a recente história da filosofia, mostrou sua fecundidade em nomes como Heidegger, Merleau-Ponty, Paul Ricoeur, Sartre, Lévinas, apenas para citar os mais conhecidos, e que não deixou de despertar o interesse em várias ciências, principalmente a psicologia. Husserl tinha consciência clara do quanto o seu projeto era inaugural e que o seu método pretendia balizar um terreno movediço. $\mathrm{Na}$ Crise a seguinte passagem é bastante clara. Depois de levantar uma questão de porque foi perdida "a unidade de desenvolvimento da filosofia transcendental”, como queria Kant, o autor constata:

um proceder de uma espécie absolutamente nova, como o de uma filosofia transcendental, para o qual faltava obrigatoriamente qualquer orientação por analogia, só poderia pairar à maneira de uma antecipação instintiva (HUSSERL, 2012, 161).

O que o método da epoché fenomenológica tem de original consiste justamente em ter compreendido como deve proceder a filosofia transcendental, como os seus problemas devem ser encarados. Ao ampliar e radicalizar o significado do ego cogito, alterando com isso a compreensão da consciência e 
da ciência da consciência em bases não objetivistas, um passo novo foi realmente dado. Quanto às precariedades assinaladas, elas são consequência desta originalidade, e podem ser vistas de duas formas, ambas com respaldo na história: ou como dificuldades insuperáveis ou como abertura de possibilidades de novas investigações.

\section{Referências}

DARTIGUES, André. O que é fenomenologia? Tradução de Maria José J. G. de Almeida. São Paulo: Moraes, 1992.

HUSSERL, Edmund. A ideia da fenomenologia. Tradução de Artur Mourão Lisboa: Edições 70.

A crise das ciências europeias e a fenomenologia transcendental: uma introduçáo à filosofia fenomenológica. Tradução de Diogo Falcão Ferrer. Rio de Janeiro: Forense Universitária, 2012.

A crise da humanidade europeia e a filosofia. Tradução de Urbano Zilles Porto Alegre: Edipucrs, 1996.

\section{Ideias para uma fenomenologia pura e para uma}

filosofia fenomenológica: introdução geral à fenomenologia pura. Tradução de Márcio Suzuki. Aparecida: Idéias \& Letras, 2006.

Meditaçóes cartesianas. Tradução de Frank

Oliveira. São Paulo: Madras, 2001. 
HUSSERL, Edmund. Cartesianische Meditationen und Pariser Vortrage. Husserliana I. Netherlands: Martinus Nijhoff, 1950. . Ideen zu einer reinen Phänomenologie und phänomenologischen Philosophie: Zweites Buch, Phänomenologische Untersuchungen zur Konstitution. Husserliana IV. Netherlands: Martinus Nijhoff, 1952.

FABRI, Marcelo. Edmund Husserl e a busca da verdade: notas sobre as investigaçôes lógicas. Unimar, [s.1.], v. 19, n.1, p. 281-298, 1997.

KANT, Immanuel. Crítica da razáo pura. Tradução de V. Rohden \& U. B. Moosburger. São Paulo: Nova Cultural, 1996.

KELKER, Arion L.; SCHÉRER, René. Husserl. Tradução de Joaquim João Coelho Rosa Lisboa: Ediçóes 70. 1982.

MOURA, Carlos Alberto R. de. Crítica da razão na fenomenologia. São Paulo: Nova Stella EDUSP, 1989. Racionalidade e crise. São Paulo: Discurso Editorial: Editora da UFPR, 2001.

PORTA, Mário A. G. Estudos neokantianos. São Paulo: Loyola, 2011. 